\title{
The Impact of The Structural Funds on Competitiveness of Small and Medium-Sized Enterprises
}

\author{
- Vojtovic Sergej
}

\begin{abstract}
The article deals with the analysis of the use of EU Structural Funds as the main tool of cohesion policy. The cohesion policy aims to reduce economic and social disparities in regional development. A part of that policy is financing of small and medium-sized enterprises from the Structural Funds for the purposes of their impact on the economic development of underdeveloped regions and to increase the competitiveness of small and medium-sized enterprises. The main focus is on determining the effect of EU Structural Funds on competitiveness of SMEs in Slovakia in the programming period 2007-2013. Based on the empirical research, we have analysed the data and we found out how the management of small and medium-sized enterprises assesses the use of EU Structural Funds and their impact on the competitiveness of enterprises managed by them. The results of our analysis and research indicate signs of an inefficient use of financial support from the Structural Funds, which is often directed to solve diverse acute economic problems. However, these funds do not increase their competitiveness.
\end{abstract}

Keywords: Structural Funds, economic growth, innovation, competitiveness, small and medium-sized enterprises JEL Classification: M10, O31, R11

\section{INTRODUCTION}

Small and medium enterprises are an integral part of the structure of production in developed countries of the world. They significantly contribute to fulfilment of the most important indicators of the national economy development. The European Union and other developed countries put a lot of emphasis on supporting the development of SMEs. These enterprises significantly contribute to the gross domestic product and the added value, e.g. in employment, in the trade balance, etc. Especially from this perspective, supporting SMEs is one of priorities of the European Commission in the context of "economic growth, job creation and economic and social cohesion" (Európska komisia, 2006). EU efforts in support of SMEs in the programming period 2007-2013 were focused on the area of small and medium enterprises, innovation and competitiveness. Precisely these priorities could help to strengthen economic and social cohesion and to reduce disparities between the levels of development in different regions.

The European Regional Development Fund and its Operational Programme: Competitiveness and Economic Growth can be considered to be the most important financial instrument, respectively the Structural Funds to support SMEs, of which priority is to foster employment and competitiveness of SMEs on the national and international level. The largest volume of financial resources that have come to the regions and that have already helped to improve the competi- 
tiveness of small and medium-sized enterprises and to ensure sustainable development has come through the European Regional Development Fund (ERDF). The support from the Regional Development Fund, inter alia, includes financing of business activities and innovations, e.g. business consulting, innovative technologies and management systems in SMEs, eco-innovation, and a better use of ICT.

Considerable financial resources have been directed to the improvement of regional and local business environment for SMEs (improving access to capital for SMEs in the process of formation and growth, improving the business infrastructure and services to support SMEs, enhancing regional and local capacities for research and development and innovation, extension of capacities for enterprise collaboration, innovation, etc.). Other important areas of funding from the Regional Development Fund were interregional and cross-border cooperation of SMEs and investment in human resources. (Európska komisia, 2006). The European Regional Development Fund has also helped to finance various investment projects in the public sector, such as the construction of railways, construction of drains, support of start-ups, development of sports and sports facilities, remediation of residential buildings, healthcare infrastructure, strengthening of cooperation between businesses in the border regions and the like.

Official documents of the EU institutions and national public authorities have dealt with evaluating the effectiveness of cohesion policy. Nevertheless, one would expect greater attention to assessing the results, particularly in terms of efficient use of funds during the next programming period. Even though more than two years have passed since the end of the programming period 2007-2013 and receiving the financial support from the designated funds, a complex expert analysis and evaluation of the effectiveness of the financial resources of their provider (responsible for the EU institutions) as well as recipients of funds from the European Regional Development Fund (governmental institutions of each country as well as small and medium enterprises) is still missing. Regarding the analysis of the effectiveness of cohesion policy, Slovak domestic studies and especially those at the level of SMEs were focused primarily on programme documents. However, almost none of them analyses large sets of data at micro level, which would reflect specific indicators of economic growth, economic efficiency and competitiveness of SMEs.

Therefore, many questions remain unanswered. What was the extent of reducing economic and social differences between regions under the influence of spending from the European Structural Funds? What was the impact of financial support for small and medium-sized enterprises in the regions to reduce regional disparities? What significance had drawing of funds from the Structural Funds for the competitiveness of SMEs?

We will not try to answer all these questions in this article. Based on evaluation of the management of small and medium-sized enterprises, we will try to answer the question whether the drawing of funds from the Structural Funds had an impact on involvement of SMEs in technology transfer, science, research and innovation, and whether or not the financial support from Structural Funds helped to increase the competitiveness. In the first part of the article, we will analyse processes of drawing and the use of funds from EU Structural Funds and individual cases of evaluating their efficiency according to the objectives set. In the second part of the article, we will present the methodological principles and practices for our investigations, methods 
and techniques used to obtain the necessary data. In the third part of the article, we discuss our results in the context of other authors' findings.

\section{THEORETICAL BACKGROUND}

The EU policy regarding the support for small and medium enterprises in the stated programming period was focused mainly on their cooperation with research and technological institutions in order to strengthen their innovation and research skills and to increase their competitiveness. The objective of this EU support was to ensure that all businesses have equal conditions in the market and that companies could trade under fair conditions. Their aim was to make Europe an attractive place for investors, to support the economic growth of strategically important industries, and also to help manufacturing companies to be competitive on the European and world markets.

The European Commission indicates that "the promotion of small and medium is one of the priorities of the European Commission in the context of economic growth, job creation and economic and social cohesion" (Európska komisia, 2006). The importance of SMEs and their competitiveness for the EU was declared by introducing the initiative Small Business Act (SBA) adopted by the European Council in 2008. The initiative emphasized the need for support measures for small and medium-sized enterprises which will provide favourable conditions and benefits for this important segment of economy.

According to the EU Treaty no. 158, the main objective of regional policy was "promoting its overall harmonious development by strengthening economic and social cohesion, reducing disparities between the levels of development of the various regions and the backwardness of the least favoured regions or islands, including rural areas.” (Ministerstvo hospodárstva, 2015a). The Structural Funds also have been regarded as the most effective tool in support of EU Cohesion Policy and the priority tool to support the development of SMEs. Through the Structural Funds, the European Union sought to ensure economic and social equilibrium to address regional disparities and to increase the growth potential in the country or region to which funds were allocated. (Sierhej \& Rosenberg, 2007).

The European Commission has prepared a vision for the new programming period, which was apparently based on the conclusions of the overall success of the implementation of projects in the previous programming period. The European Commission emphasized in this context that "Structural Funds, which are long-term supporters of SMEs, has now become an important tool in achieving the objectives of the Europe 2020 strategy for smart, sustainable and inclusive growth". (Európska komisia, 2013).

Despite the fact that there was a clear political vision of the importance of supporting small and medium enterprises through the Cohesion Policy and of other specific measures to individual countries, the question of its effectiveness as a whole arose during the financial and debt crisis. Considering the fact that the majority of Member States are highly in debt (in terms of debt ratio and high government expenditure to GDP), the EU should not support measures that are not socially and economically effective. 
Although the process of convergence between EU countries and regions brings positive results, questions arise if it was really due to the cohesion policy. In principle, there are no doubts that political decisions, most importantly effective mechanisms and instruments for their implementation have a positive impact on the convergence process. For example, Ederveenet et al. (2002) came to the conclusion that we can observe partially the positive impact of subsidies from the European Structural Funds to the convergence process. A similar conclusion was expressed by Beutel (2002), Hagen and Can (2008), who investigated the impact of cohesion policy on economic growth. According to them, one can observe only a modest impact of cohesion policy on regional economic growth. Ecke and Turk (2006) emphasized positive aspects of the impact of cohesion policy on economic growth and regions convergence. They also came to the conclusion that the system of drawing funds from Structural Funds is not very effective, and therefore, they prioritize supporting human capital, innovation, research and development.

The impact of individual aspects of cohesion policy on regional integration processes in terms of application to the specifics of the Czech Republic is evaluated with milder critical statements in the works of Blazek and Vozáb (2006), Mirosnik et al. (2014) and other authors. In these works, authors present an ex-ante analysis of cohesion policy in Czech Republic and determine its strong and weak aspects. In addition, the authors conduct a process analysis of the First Action Programme in the context of the implementation of the Territorial Agenda of the EU with the impact on rural regions, allocation mechanisms of cohesion funds in accordance with the objectives, etc. The conclusions are pointing out to the unevenness in distribution of funds and the ambiguity of the impact of cohesion policy on reduction of regional disparities.

The assessments of the effectiveness of regional development support from the Structural Funds in Slovakia were usually based on the documents relating to EU programmes, statements and reports of government institutions and so on. (Ivaničková 2007; Rumanovská, 2011; Kiss et al, 2013; Ivanova \& Koišová, 2014). When it comes to the methodology, the calculation of the efficiency of use of financial support from the Structural Funds was as a rule based on macroeconomic indicators, which were not quite appropriate for assessing the effectiveness. Because of the chosen methodology, the evaluation of the impact assessment of financial support for the development of small and medium-sized enterprises and the integration of the regions is more positive when compared with assessments of previously mentioned studies.

There is no dispute over the existence of the regional convergence in the EU. Nevertheless, it remains unclear to what extent the process of convergence is powered by supportive mechanisms of the European cohesion policy and to what extent it is driven by mechanisms of a modern market economy. Despite the fact that general comments regarding the cohesion policy are rather positive, one cannot ignore the critique aimed at its effectiveness.

According to Rodriguez-Pose and Fratesi (2004), there is no positive effect of the Structural Funds for convergence countries and regions in EU. Bachtler and McMaster (2008) took a rather critical stance towards the impact of EU cohesion policy on regional integration and the role of regional institutions in Central and Eastern Europe. Not only have they rigorously evaluated both technical variables and complex aspects of the EU Structural Funds, but they also have divided the processes of the EU Structural Funds management and drawing into individual stages, and thus pointed out differences when it comes to the regional involvement in Structural 
Funds. In addition, they conducted cross-national analysis of practical experience with drawing the resources from EU Structural Funds. Their conclusions question the universally accepted assumption that the Structural Funds contribute to the development of regional structures and competences and lead to "stronger regions". On the contrary, they argued that there is no guarantee that the Structural Funds support the regional integration processes in Central and Eastern Europe in a short or medium period context.

Considering the differences and contradictions in the findings and assessment of the efficiency of European cohesion policy, there were doubts not only about this policy's formulation and its implementation guidelines, but also about the methodological procedures of calculation and assessment of its results. Wostner and Slander (2009) comment on that error. According to them, in spite of all conducted analyses and assessments and the positive proclamations about the impact of European cohesion policy on the development in integration of regions, EU leaders cannot be truly sure whether the enormous amounts of financial resources invested into European cohesion policy have been spent efficiently. The fact that research papers and reviews on the effectiveness of cohesion policy often arrive to different conclusions raises questions not necessarily only about the nature of the cohesion policy but also about the actual evaluation process. Moreover, they emphasized that the studies as a rule are based on macroeconomic analysis and the discrepancies in their findings are caused by the chosen methodology and by the fact that the direct macroeconomic approach is not adequate to the principle of cohesion policy. (Wostner \& Slander, 2009).

Mirošník tried to answer the question why the absolute majority of the analysis and evaluation of the effectiveness of EU cohesion policy used macroeconomic approach. According to him, the reason is mainly sufficiency and availability of macroeconomic data. On the other hand, the bad quality and difficulties in obtaining micro-economic indicators are an important obstacle for an adequate assessment of the impact of Structural Fund support on the growth and performance of businesses and regions (Mirošník, et al. 2014).

One of the few studies that have used microeconomic approach to the analysis and evaluation of the effectiveness of EU cohesion policy was the work of Italian authors C. Bernini and G. Pelegrini (2011). It analysed the impact of EU funds on the performance of companies in the Italian regions in the period of 1996-2004 on the basis of business accounting data. It was found that subsidized companies compared to non-subsidized companies have increased the scope of its production and employment indicators. The unexpected finding was that labour productivity in the subsidized companies had decreased (Bernini \& Pelegrini, 2011).

Bondonio (2012) examined the impact of EU funds on the performance of mainly small and medium enterprises in Italy and he made similar conclusions. According to his findings, in principle, there is no positive impact of subsidies on labour productivity and on employment in supported SMEs. Simultaneously, he discovered that small businesses are more cost effective than larger companies. He concluded that if he analysed only small businesses, so he could see a slightly positive effect of financial support on labour productivity in small businesses. Bondonio as well as his colleagues Bernini and Pelegrini was convinced in the overall assessment of the impact of EU financial support on productivity in small and medium-sized enterprises that use of financial support from EU funds did not help to increase the competitiveness of small and 
medium-sized enterprises. In addition, in another study assessing the impact of cohesion policy on small and medium-sized enterprises in Central Europe, the conclusion was also negative. Its authors emphasize that if the Structural Funds were used optimally, it could have brought positive results (Potluka, et al., 2010).

Overall, there are only very few studies of the effectiveness of using financial support from the Structural Funds, which are methodologically similar to that of Bondonio (2012) or Bernini \& Pelegrini (2011). In addition, we do not know any study that analysed and evaluated the effectiveness of financial support from the Structural Funds in accordance with the objectives of the Operational Programme Competitiveness and Economic Growth. That means a study which identified and evaluated the impact of Structural Funds on the competitiveness of SMEs on the basis of their involvement in science, research and innovation, and transfer of innovation and new technologies into production.

\section{RESEARCH OBJECTIVE, METHODOLOGY AND DATA}

Formation of the priority actions of the Operational Programme Competitiveness and Economic Growth was based on identifiable disparities and the principle of territorial development defined in the National Strategic Reference Framework of the Slovak Republic. The regions did not use their potential in sufficient scale for field of research and innovation according to this document. This potential could be their significant source of competitive advantage. At the same time, the companies have shown very little interest in the introduction of innovations into the process of production. That is the reason, why the interventions implemented as a part of the initiative 'Innovations and technological transfers' mostly aimed to modernize production machinery and work processes, to creating new jobs, to invest into R\&D companies, to introduce measures connected with the support of research and innovations in the small and medium sized companies, to support research centres, etc. (Ministerstvo hospodárstva, 2015).

The main objective of this study was to determine how the management of SMEs perceives and assesses the impact of the funding received from the EU Structural Funds under the Operational Programme Competitiveness and Economic Growth on development activities in science, research and transfer of innovations and new technologies in the production with the aim to improve competitiveness and economic growth of SMEs.

To achieve this goal, we have used empirical data from a survey carried out by the method of a structured interview, which was conducted in the years 2014-2015 and which focused on the quality of the business environment of SMEs. This survey studied the impact of financial support from the Structural Funds on economic development of SMEs as one of several factors of business environment.

In this study, we analyse and measure the impact of EU Structural Funds on competitiveness and growth of SMEs based on thinking and evaluation of particular managers of small and medium-sized enterprises. We consider this method of research to be one of several standard and appropriate methods in the system of micro-economic approach to this issue. The chosen method neither challenges not replaces analyses and assessments based on accounting data and macroeconomic indicators. We consider managers of enterprises to be experts who are research 
units in our survey. Firstly, managers of enterprises are involved in activities connected with preparation of project proposals to receive financial support from the Structural Funds, the actual process of receiving financial resources from these funds and the final use of gained resources. Secondly, analyses, evaluations and decisions regarding these activities are the subject of their daily work. In addition, when we add human creativity, intuition, ability to estimate and affect event or context, this synergistic result of this evaluation may be more adequate and accurate than assessment based on accounting data.

Therefore, in our empirical survey, we did not perceive managers of enterprises as statistical sampling unit, but as an expert unit. As a result, the very essence of this empirical survey and assessment of its representativeness is different from the classical empirical survey of statistical units of the sample. In this case, the information value of the empirical data that we obtained is independent and is not assessed on the basis of the statistical amount of reconnaissance units.

The object of investigation was a suitably selected research sample of the research group of 285 SMEs. Our main group consisted of 168 of these enterprises that received financial support from the Structural Funds in the programming period 2007-2013 under the operational program Competitiveness and economic growth. The remaining 117 enterprises that did not receive financial support in the stated period were named the control group. We divided our research sample into small enterprises and middle-sized enterprises. We relied on official statistics that state that more than $80 \%$ of small businesses are composed of individual entrepreneur, and the rest employ 1-49 workers. In our research, the group of businesses that we considered small consists of individual entrepreneurs and companies who are managed by a single manager, regardless of overall the number of employees. As a result, our research sample included 36 small and 132 medium-sized enterprises (total of 168) which received financial support from the Structural Funds and from 56 small and 61 medium-sized enterprises (total of 117) which did not receive financial support.

For the purposes of our research, we used answers to the following closed question of the structured interview: "What were the significant economic results for your company affected mainly by financial support from the Structural Funds in the programming period 2007-2013. (Select 3 most important results by you)." For the enterprises that did not receive support from the Structural Funds, the question was: "What were significant economic results for your company in the period 2007-2013. (Select 3 most important results)."

We differentiated between responses of senior managers (directors) of small enterprises, directors of medium-sized enterprises and of managers - for example directors of individual departments or production sections. Since the group of small businesses consisted of individual entrepreneurs (who are also directors) or companies that do not have other directors, the number of responses was equal to the queried number of small businesses. The number of responses in the group of medium-sized enterprises was equal to the number of surveyed directors and the number of other managers - from 1 to 3 in each company, depending on its size. The number of ratings is equivalent to 3 times the number of received structured interviews (see Tab. 1) in particular economic results. 
Tab. 1 - The numbers of surveyed enterprises, received interviews and evaluation of economic results. Source: author's own survey

\begin{tabular}{|l|c|c|c|c|c|c|}
\hline \multirow{2}{*}{$\begin{array}{l}\text { Enterprise } \\
\text { groups }\end{array}$} & \multicolumn{3}{|c|}{ Supported } & \multicolumn{3}{c|}{ Unsupported } \\
\cline { 2 - 7 } & Small & \multicolumn{2}{|c|}{ Medium } & Small & \multicolumn{2}{c|}{ Medium } \\
\hline $\begin{array}{l}\text { The number of } \\
\text { enterprises }\end{array}$ & 36 & \multicolumn{2}{|c|}{132} & 56 & \multicolumn{2}{c|}{61} \\
\hline $\begin{array}{l}\text { Groups of re- } \\
\text { spondents }\end{array}$ & Directors & Directors & Managers & Directors & Directors & Managers \\
\hline $\begin{array}{l}\text { The number of } \\
\text { interviews }\end{array}$ & 36 & 132 & 286 & 56 & 61 & 147 \\
\hline $\begin{array}{l}\text { The number of } \\
\text { evaluation }\end{array}$ & 108 & 396 & 858 & 168 & 183 & 441 \\
\hline
\end{tabular}

Statistically significant differences between the responses of defined groups of respondents in supported and unsupported enterprises were calculated by using the Pearson's correlation coefficient with significance level of 5\%. Statistically significant differences in percentages indicators of respondents' answers were calculated by means of the $\chi^{2}$ - coefficient.

\section{RESULTS AND DISCUSSION}

The overall direction of the Operational Programme Competitiveness and Economic Growth was based on macroeconomic factors, which affected the character of supported activities. To measure the success and benefits of using EU funds, there have been identified criteria such as the number of supported projects, new enterprises, and private investment in innovative projects. The criteria for assessing the effectiveness and efficiency of use of financial resources from the Structural Funds in enterprises were created in line with the main objective - increasing competitiveness. These included mainly innovation and transfer of new technologies, investment in research and development, introduction of innovative processes, increase of revenues, job creation, investments in the development of SMEs and the creation of sustainable jobs and so on. (Európska komisia, 2013).

Some of these criteria may be an indication of enhancing business competitiveness but they are not a source or cause for this. For example, an increase in revenue or job creation may be an indication of increasing competitiveness only if its source is the growth of labour productivity, the introduction of new production techniques or new technologies, etc. Simultaneously, an increase in revenue or job creation may be the result of using more factors of production; nevertheless, by itself it does not necessarily lead to a labour productivity growth or an improved competitiveness.

The list of indicators of economic activity of enterprises, which we offered as potential responses, was based mainly on European Commission documents and the Operational Programme Competitiveness and Economic Growth. We assigned them to a group of activities that increase productivity, profit, and thus increase competitiveness of the company itself in the short and es- 
pecially in the long term. Those mainly include: transfer of innovations and new technologies in production, labour productivity growth, introduction of innovative approaches to production, value added growth and investment in research and development. The growth of production, sales, profits, market share or job creation by themselves are not necessarily the reasons behind improved business competitiveness and its sustainability.

The Ministry of Economy assesses the success and effectiveness of using financial support from the Structural Funds in accordance with the criteria mentioned above. For example, its annual report states that the greatest number of new jobs (14200) was created thanks to the initiative Innovation and growth of competitiveness. $84 \%$ (11860) of these were created in small and medium-sized enterprises. The added value increased by $105.8 \%$ over the previous year. The sales decreased by $5 \%$ in the subsidized companies over the previous year, but when compared with the initial value of 2007 the sales increased by $22 \%$. The enterprises introduced into production around 700 innovation of production processes thanks to use of funds. Innovative processes contribute significantly to their development. (Ministerstvo hospodárstva, 2015b).

We have found out in our survey that the enterprises that we classified as small had the greatest difficulties in obtaining support from the Structural Funds. Despite the fact that these companies are the most numerous in the structure of small and medium-sized enterprises, it was difficult to amass a sufficient number of small enterprises that received financial support from the Structural funds for our research sample.

According to evaluation of the directors of small enterprises, the financial support from the Structural Funds contributed to a growth of revenues, production volume and profit, and a moderate increase in labour productivity. (See Tab. 2). The majority of directors of small enterprises recognized these effects, but only $36 \%$ of them had seen the growth of labour productivity, which is at the level of statistical significance.

Tab. 2 - The economic results of enterprises which benefited from financial support from the Structural Funds (evaluation managers, $\mathrm{N}$ and \%). Source: author's own survey

\begin{tabular}{|l|c|c|c|c|c|c|}
\hline \multirow{2}{*}{ Economic results } & \multicolumn{2}{|c|}{$\begin{array}{c}\text { Directors of small } \\
\text { enterprises }\end{array}$} & \multicolumn{2}{|c|}{$\begin{array}{c}\text { Directors of me- } \\
\text { dium enterprises }\end{array}$} & \multicolumn{2}{c|}{$\begin{array}{c}\text { Managers of me- } \\
\text { dium enterprises }\end{array}$} \\
\cline { 2 - 7 } & $\begin{array}{l}\text { Number } \\
\text { of replies }\end{array}$ & $\%$ & $\begin{array}{c}\text { Number } \\
\text { of replies }\end{array}$ & $\%$ & $\begin{array}{c}\text { Number } \\
\text { of replies }\end{array}$ & $\%$ \\
\hline The growth of revenues & 31 & 86.1 & 58 & 44.3 & 145 & 51.9 \\
\hline $\begin{array}{l}\text { Transfer of innovations } \\
\text { and new technologies to } \\
\text { production }\end{array}$ & 0 & 0.0 & 16 & 12.1 & 49 & 17.1 \\
\hline $\begin{array}{l}\text { Labour productivity } \\
\text { growth }\end{array}$ & 13 & 36.1 & 38 & 28.8 & 67 & 23.4 \\
\hline $\begin{array}{l}\text { The growth of the mar- } \\
\text { ket share }\end{array}$ & 4 & 11.1 & 8 & 6.1 & 59 & 21.2 \\
\hline Creation of new jobs & 6 & 16.6 & 51 & 39.3 & 129 & 45.1 \\
\hline
\end{tabular}




\begin{tabular}{|l|c|c|c|c|c|c|}
\hline $\begin{array}{l}\text { The growth of produc- } \\
\text { tion volume }\end{array}$ & 26 & 72.2 & 83 & 63.7 & 137 & 47.9 \\
\hline $\begin{array}{l}\text { The introduction of in- } \\
\text { novative practices }\end{array}$ & 5 & 14.0 & 57 & 43.2 & 93 & 32.5 \\
\hline Profit growth & 19 & 52.7 & 46 & 35.4 & 83 & 29.0 \\
\hline $\begin{array}{l}\text { Investments into re- } \\
\text { search and development }\end{array}$ & 3 & 8.3 & 63 & 25.0 & 62 & 21.7 \\
\hline Value added growth & $\mathrm{N}=108$ & $0.0 *$ & $\mathrm{~N}=396$ & $0.0 *$ & $\mathrm{~N}=858$ & $0.0 *$ \\
\hline Total: number $/ \%$ & & & 4.5 & 34 & 12.0 \\
\hline
\end{tabular}

* The total sum of percentage points is greater than 100 because each respondent evaluated three positions in the questionnaire.

The calculation of the level of significance of the data according to $\chi^{2}$ - coefficient indicates that the significance was at the level $\mathrm{N}=9$ and more responses or $25 \%$, at $\alpha=0.05$. Economic results such as implementation of innovations and new production technologies, investing in research and development, introduction of innovative practices in production and creation of new jobs remained below the level of statistical significance. This means that financial support helped small enterprises to improve their economic indicators. However, these indicators are not likely to increase their competitiveness and especially not in the long term. In addition, in the enterprises that have experienced growth in labour productivity, they cannot expect an automatic increase in their competitiveness indicators.

The directors of medium-sized enterprises extended the spectrum of positive economic results in comparison with their colleagues from small businesses. Significant economic results were not just revenue growth, production growth, profit growth and labour productivity growth for them. The financial support from the Structural Funds contributed to the creation of new jobs, introducing innovative processes and investing in research and development. Economic results as transfer of innovation and new technologies, the growth of the market share and added value growth remained below the level of statistical significance. The statistical significance of the data according to $\chi^{2}$ - coefficient for this group of respondents is at the level $\mathrm{N}=33$ and more responses or $25 \%$, at $\alpha=0.05$.

The managers of medium-sized businesses were less optimistic than their directors. According to the managers, financial support from the Structural Funds did not affect transfer of innovations and new technologies in production, growth in labour productivity, growth in market share, growth of investment in research and development and added value growth. The production managers of medium-sized enterprises agree more with opinions of directors of small enterprises than with their superiors. Economic results that are associated with innovations and other sophisticated activities that contribute to sustainable economic development and competitiveness of enterprises remained below the level of statistical significance according to managers. The statistical significance of the data according to $\chi^{2}$ - coefficient for this group of respondents is at the level $\mathrm{N}=71$ and more responses or $24 \%$, at $\alpha=0.05$.

Evaluation of economic results of SMEs that did not have financial support from the Structural Funds as a whole is different in that they do not have such economic results, which contribute to increasing competitiveness and sustainable development. (Tab. 3). 
Tab. 3 - The economic results of enterprises that did not receive support from the Structural Funds in the period 2007-2013 (evaluation of managers, N and \%). Source: author's own survey

\begin{tabular}{|l|c|c|c|c|c|c|}
\hline \multirow{2}{*}{ Economic results } & \multicolumn{2}{|c|}{$\begin{array}{c}\text { Directors of small } \\
\text { enterprises }\end{array}$} & \multicolumn{2}{c|}{$\begin{array}{c}\text { Directors of me- } \\
\text { dium enterprises }\end{array}$} & \multicolumn{2}{c|}{$\begin{array}{c}\text { Managers of me- } \\
\text { dium enterprises }\end{array}$} \\
\cline { 2 - 7 } & $\begin{array}{c}\text { Number } \\
\text { of replies }\end{array}$ & $\%$ & $\begin{array}{c}\text { Number } \\
\text { of replies }\end{array}$ & $\%$ & $\begin{array}{c}\text { Number } \\
\text { of replies }\end{array}$ & $\%$ \\
\hline The growth of revenues & 39 & 69.6 & 37 & 60.6 & 74 & 50.3 \\
\hline $\begin{array}{l}\text { Transfer of innovations and } \\
\text { new technologies to produc- } \\
\text { tion }\end{array}$ & 1 & 1.8 & 4 & 6.5 & 11 & 7.5 \\
\hline Labour productivity growth & 27 & 48.2 & 22 & 36.0 & 39 & 26.5 \\
\hline $\begin{array}{l}\text { The growth of the market } \\
\text { share }\end{array}$ & 12 & 21.4 & 7 & 11.5 & 13 & 8.8 \\
\hline Creation of new jobs & 5 & 9.0 & 27 & 44.2 & 89 & 60.5 \\
\hline $\begin{array}{l}\text { The growth of production } \\
\text { volume }\end{array}$ & 47 & 84.0 & 39 & 64.0 & 83 & 56.5 \\
\hline $\begin{array}{l}\text { The introduction of innova- } \\
\text { tive practices }\end{array}$ & 11 & 19.6 & 16 & 26.2 & 37 & 25.2 \\
\hline Profit growth & 19 & 34.0 & 18 & 29.5 & 62 & 42.2 \\
\hline $\begin{array}{l}\text { Investments into research } \\
\text { and development }\end{array}$ & 0 & 0.0 & 8 & 13.1 & 19 & 13.0 \\
\hline Value added growth & 7 & 12.5 & 5 & 8.2 & 14 & 9.5 \\
\hline Total: number / \% & $0.0 *$ & $\mathrm{~N}=183$ & $0.0 *$ & $\mathrm{~N}=441$ & $0.0 *$ \\
\hline
\end{tabular}

* The total sum of percentage points is greater than 100 because each respondent evaluated three positions in the questionnaire.

While a certain part of the SMEs that received financial support experienced economic benefits stemming from innovations and other sophisticated activities, the enterprises without financial support experienced no such benefits. For example, small businesses according to evaluation of their directors in the period 2007-2013 increased their revenues (69\%), increased labour productivity (48\%), increased the volume of production (84\%) and profit (34\%). The impact on sustainability and competitiveness cannot be assessed without assessing causes of the growth of the mentioned economic variables. The level of statistical significance for that group of respondents was valid at $\alpha=0.05$ at level $\mathrm{N}=14$ or more responses, or $25 \%$.

Unlike the managers of small businesses, the directors and managers of medium-sized businesses perceived job creation and introduction into production of innovative practices as one of the relevant economic results. The statistical significance was at $\alpha=0.05$ at the level $\mathrm{N}=15$ and more answers or $24.5 \%$ for the directors of medium enterprises. The statistical significance was at the level $\mathrm{N}=29$ and more answers or $19.7 \%$ for the managers. Economic results that remained below the level of statistical significance are: transfer of innovations and new tech- 
nologies, growth in market share, investment in research, development and added value growth. However, it is evident that small enterprises were not successful in the effective use of financial resources from the Structural Funds in comparison with medium-sized enterprises. Mediumsized enterprises were only slightly more successful.

The overall assessment of the impact of financial support on the economic results of supported and unsupported SMEs does not suggest the indication of relevant differences according to our selected group of managers. Pearson's calculated correlation coefficients show a strong or moderate positive correlation with the tendency of high variability of variables (from $r=0.71$ to $r=0.91)$. Minimum relevant differences are recognized in the economic results of enterprises in comparison with the evaluation between supported and unsupported enterprises. A strong positive correlation $(r=0.93)$ has a hierarchy of assessment of supported and unsupported business according to the directors of small businesses, the directors of medium enterprises $(r=0.88)$ and the managers $(\mathrm{r}=0.92)$. All the values of the coefficients of correlation $(\mathrm{r})$ are valid when $\mathrm{p}<0.05$.

We have observed that small enterprises, whether or not they received financial support, have the same economic results. The situation was very similar in the case of medium-sized enterprises. A common feature in these evaluations is that neither unsupported, which is understandable, nor supported enterprises (especially small enterprises) achieved the economic results, which increase their competitiveness, contribute to sustainable development, and which also fulfil the vision of the EU Structural Funds and the criteria for the operational Programme Competitiveness and economic growth.

The persisting differences in evaluations of the Structural Funds' effectiveness provide sceptics with arguments about the effectiveness of EU Structural Funds. The European Union has set itself the goal to become the most competitive and dynamic economy based on innovation and knowledge with a high level of integration of countries and regions. According to Bachtler and Gorzelak (2007), the differences between rich and poor regions grew. This situation persists for regions and countries of the EU. For example, it is known that Slovakia was one of the fastest growing EU economies in the last decade. Nevertheless, regional disparities increased and the economic growth mainly happened in the wealthier regions of the western part of the country (Slovak Business Agency, 2015). Slovakia does not converge with the developed EU countries, and EU countries do not converge with world leaders in transfer of innovation, new technologies and knowledge-based economy. The cause of this situation may be that half of the Member States of EU25 (today it is even more) have limited innovation capacities according to Tsipouri (2004).

According to our findings, small enterprises are the least successful in drawing financial support from the Structural Funds. There are various possible explanations of this state. One of them may be a preceding idea of L. J. Tsipouri about limited innovation capacity. We have already mentioned that individual entrepreneurs are the real subjects of an absolute majority of small enterprises. It would be naive to think that an individual entrepreneur, who provides service and repairs forklifts in stock in a nearby supermarket, will also be able to create sufficient capital that can be invested in long-term issues such as research and development, transfer of innovation and new technology, and so on. Moreover, many of these individual entrepreneurs are not 
executives as such, and they only work as independent contractors or employees. This means that small enterprises do not have and cannot have the necessary capital, financial, technical, organizational and human resources for the achievement of economic results that will contribute to their sustainable development and improving competitiveness in principle. This applies also to several medium enterprises, which also do not have the above-mentioned capacities and resources (Bhaird, 2010).

Another reason for failure is according to Bachtler and Gorzelak (2007) that economic mechanisms are structurally underdeveloped in new member countries. These countries are unable to effectively absorb financial support offered by the Structural Funds in conformity with the objectives. If we examine this argument in detail, this issue includes social and legal systems, the concept of democracy and not only in the sphere of management of public affairs, but also in the system of economic relations and insidefactory democracy, value systems, traditions, moral of people, etc. Many authors openly speak and write not only about ineffectiveness of the use of funds, but also about clientelism, lobbying and overt corruption at the stage of applying for financial support from the Structural Funds as well as in the process of drawing (Aidt, 2009; Babitz \& Havran, 2006).

If the system is not sufficiently developed for drawing of financial support, why was not support policy made in such a form which is suitable for the existing underdeveloped economic system? Does it mean that the EU cohesion policy was not fully adequate to the nature and status of SMEs? Perhaps the authors behind the funding policy lack the inclination towards reflection and criticism, and the recipients of financial support are interested primarily in receiving this support and not in the quality of distribution policy. It is not possible to answer the above mentioned questions, nor to answer a question about the unpreparedness of the economic systems of the new member states without further academic research and generalization of practical experience.

In the case of Ireland, their successful use of EU funds was caused by Europeanization and state adaptation to the values of the policy and practice of the EU, and by reorientation of domestic policies, practices and preferences to create a multi-level management (Börzel \& Risse, 2008). There have been some concerns about sustainability of the impact of knowledge transfer from management and partnership of the Irish multi-level model in the context of a formal system of the Irish Government later. In general, if the required impact of EU cohesion policy should be sustainable in the long term, then it is necessary to pay attention to the effective measurement and explain the impact of EU policies on the country and its economy (Adshead, 2014).

One of the arguments attempting to explain the inefficiency of using the financial support from EU Structural Funds (regarding the competencies of both EU and member states alike) could be that the companies lack a straightforward strategy towards sustainable development, competitiveness and knowledge economy. The previous experience suggest two possible scenarios: either to implement the prospective measures in all the companies (as it happened in Ireland); or to focus only on the dynamically developing companies that would thus integrate into the developed global system, while leaving the rest of the economy in a permanent low-cost and low-competitiveness trap. The former is a win-win scenario for the European system of innovation, whereas the latter is second-best. (Tsipouri, 2004). The solution of this problem requires not only evaluation and generalization of previous experience but also further academic and scientific research. 


\section{CONCLUSION}

The evaluations based on the analysis of macroeconomic data point out the inefficient use of financial support coming from the EU Structural Funds. Similarly, the results obtained through the analysis of microeconomic indicators and the accounting of the selected companies, which received financial support from Structural Funds, also confirm this inefficiency, both when it comes to the funds' overall goals and the conditions of their granting and redistribution.

In our research, we have assessed the efficiency of EU Structural Funds use based on the evaluations of the managers of small and middle-sized companies. The overall conclusions of our research do not differ from those mentioned above. According to the directors and operations managers of small and middle-sized companies, the economic results of companies that received support are comparable with those achieved by the companies without the financial support. In general, the funded companies did not achieve such economic results which would contribute to their competitiveness, sustainable development, and which would fulfil the criteria of EU Structural Funds and the Operational Programme: Competitiveness and Economic Growth.

The results of our research conclude that small companies were the least successful when it comes to obtaining the financial support from the Structural Funds. The intended goals of granting financial support from the Structural Funds, the criteria of its granting and the findings of the analyses conducted by other authors all suggest that small companies as such do not have organizational, capital and human resources needed for efficient use of allocated financial support.

The further research into the nature and the structure of new member states' economic systems could contribute to answering the question why especially small companies are unsuccessful in their use of the Structural Funds; however, this topic remains to be researched properly. Are the new member states' economic relations and mechanisms of inner democracy, their value systems, traditions, morale, etc. developed enough, so that these states would be able to use the financial support from EU Structural Funds efficiently and in accordance with the stated goals? If the answer is 'no', then it implies that EU cohesion policy as such does not correspond with the current state and the nature of small and middle-sized companies in the new member states. However, neither this question nor the question regarding the lack of preparedness of new member states can be answered without further academic research.

One of the possible explanations why small and middle-sized companies in the new member states are so inefficient in their use of EU Structural Funds could be the lack of a clear strategy that would lead to a transition towards sustainable development, competitiveness and knowledge economy. Despite the fact that the previous results of this process pointed our two possible strategies, neither EU nor the governments in the new member states managed to make a final decision on which one to support and follow. To explain further, the decision was whether to support the prospective measures in all companies or only in those developing dynamically. The former option is not a guarantee of a successful convergence of economic system of new member states towards the sustainable development and increase in competitiveness. In the case of the latter strategy, the rest of the economy that remains without support will continue lagging in a permanent low-cost and low-competitiveness trap. 


\section{References}

1. Adshead, M. (2014). EU cohesion polisy and multi-level governance outcomes in Ireland: How sustainable is Europeanization? European Urban and Regional Studies, 21(4), 416-431. DOI: $10.1177 / 0969776413490426$

2. Aidt, T. (2009). Corruption, institutions and economic development. Oxford Review of Economic Policy, 25(2), 271-291. DOI: 10.1093/oxrep/grp012

3. Babitz, M., \& Havran, R. (2006). Strukturálne fondy EÚ na Slovensku a možnosti ich transparentnejšieho vyư̌ivania. Bratislava: Adin, s.r.o.

4. Bachtler, J., \& Gorzelak, G. (2007). Reforming EU cohesion policy: a reappraisal of the performance of the Structural Funds. Policy Studies, 28(4), 309-326. DOI: dx.doi.org/10.1080 /01442870701640682

5. Bachtler, J., \& McMaster, I. (2008). EU Cohesion Policy and the Role of the Regions: Investigating the Influence of Structural Funds in the New Member States. Environment and Planning C: Government and Policy, 26(2), 398-427. DOI: 10.1068/c0662

6. Bernini, C., \& Pellegrini, G. (2011). How is growth and productivity in private firms affected by public subsidy? Evidence from a regional policy. Regional Science and Urban Economics, 41(3), 253-265. DOI: 10.1016/j.regsciurbeco.2011.01.005

7. Beutel, J. (2002). The Economic Impact of Objective 1 Interventions for the Period 2000_2006. European Commission Final Report. Retrieved from http://ec. europa.eu/regional_ policy/sources/docgener/studies/pdf/objective1/final_report.pdf

8. Bhaird, C. M. (2010). Resourcing Small and Medium Sized Enetrprises. Springer Verlag: Berlin.

9. Blažek, J., \& Vozáb, J. (2006). Ex-ante evaluation in the new memberstates: the case of the Czech Republic. Regional Studies, 40(2), 237-248. DOI: 10.1080/00343400600600603

10. Bondonio, D. (2014). Revitalizing regional economies through enterprise support policies: an impact evaluation of multiple instruments. European Urban \&Regional Studies, 21(1), 79103. DOI: $10.1177 / 0969776411432986$

11. Börzel, X., \& Risse, X. (2008). Europeanization and Multilevel Governance: Cohesion Policy in the European Union and Britain. Rowman\&Littlefield, 2008.

12. Eckey, H., \& Turk, M. (2006). Convergence of EU-regions: A Literature Report. Discussion Paper, No. 80.

13. Ederveen, S. et al. (2002). Funds and Games: the Economics of European Cohesion Policy. CPB Special Publication, No. 41. Retrieved from: http://www.cpb.nl/publicatie/funds-andgames-economics-european-cohesion-policy

14. Európska komisia. (2006). Nová definícia malých a stredných podnikov.Uživatel'ská príručka a modelové vyblásenie. Úrad pre vydávanie publikácií Európskej únie, Luxemburg.

15. Európska komisia. (2013). Ako využivat’ śtrukturálne fondy na politiku týkajúcu sa MSP a podnikania. Belgicko.

16. Hagen, T., \& Mohl, P. (2008). Which Is the Right Dose of EU Cohesion Policy for Economic Growth? ZEW DiscussionPaper, 8(104). Retrieved 23rd February, 2016 from: 
http://193.196.11.222/pub/zew-docs/dp/dp08104.pdf

17. Ivaničková, A. (2007). Inovované programovanie regionálnej politiky Európskej únie v programovacom obdobi 2007-2013. Bratislava: EKONÓM.

18. Ivanová, E., \& Koišová E. (2014). Interregional disparities in the Slovak and Czech Republic. Economic \& tourism. Conf. SGEM Sofia: STEF92, Vol. IV, 405-412.

19. Kiss, I. a kol. (2013). Európske fondy v praxi. Bratislava: ANGEMY, s.r.o.

20. Kozubíková, L., Belás, J., Bilan, Y., \& Bartoš, P. (2015). Personal characteristics of entrepreneurs in the context of perception and management of business risk in the SME segment. Economics and Sociology, 8(1), 41-54. DOI: dx.doi.org/10.14254/2071-789X.2015/8-1/4

21. Ministerstvo hospodárstva SR. (2015a). Operačný program Konkurencieschopnost' a hospodársky rast.

22. Ministerstvo hospodárstva SR. (2015b). Výročná správa o vykonávani Operačného programu Konkurencieschopnost' a hospodársky rast za rok. 2014.

23. Mirošník, K. et al. (2014). Statistical analysis of cohesion funding in the Czech Republic. Procedia Economics and Finance, 12, 437-444.

24. Potluka, O. (2010). Impact of EU Cohesion Policy in Central Europe. Leipzig: Leipziger Universitätsverlag.

25. Rodriguez-Pose, A., \& Fratesi, U. (2004). Between development and social policies: the impact of European Structural Funds in objective 1 regions. Regional Studies, 38(1). 97-113. DOI: $10.1080 / 00343400310001632226$

26. Rumanovská, L. (2011). Politika EÚ v oblasti podpory malých a stredných podnikov. Programy Európskej únie a ich financovanie. Nitra: SPU.

27. Sierhej, R., \& Rosenberg, Ch. (2007). Interpreting EU Funds Data for Macroeconomic Analysis in the New Member States. International Monetary Fund, 2007.

28. Slovak Business Agency. (2015). Podpora malého a stredného podnikania v Slovenskej republike: Sprievodca iniciativami. Retrieved 11th November 2015 from http://www.sbagency.sk/sites/ default/files/sprievodca_2015-fin_0.pdf

29. Tsipouri, L. J. (2004). Innovation for European competitiveness and cohesion:

Opportunities and difficulties of co-evolution. Science and Public Policy, 31(6), 465-474.

30. Wostner, P., \& Šlander, S. (2009) The Effectiveness of EU Cohesion Policy Revisited: Are EU Funds Really Additional? European Policies Research Centre.

\section{Contact information}

doc. Sergej Vojtovic, DrSc.

University of Alexander Dubchek in Trencin,

Faculty of Social and Economic Relations

Studentská 3, 91150 Trenčin, Slovakia

E-mail:sergej.vojtovic@tnuni.sk. 